\title{
Anatomic Position of the Pterion among Kenyans for Lateral Skull Approaches
}

\author{
Posición Anatómica del Pterion entre Kenianos para Abordajes Laterales de Cráneo \\ "Mwachaka, P.; **Hassanali, J. \& ${ }^{* * *}$ Odula, P.
}

MWACHAKA, P.; HASSANALI, J. \& ODULA, P. Anatomic position of the pterion among Kenyans for lateral skull approaches. Int. J. Morphol., 26(4):931-933, 2008.

SUMMARY: The pterion is a point of sutural confluence seen in the norma lateralis of the skull where frontal, parietal, temporal and sphenoid bones meet. The position of the pterion exhibits population-based variations. Location of this point is important in surgical approaches to the anterior and middle cranial fossae. Specific measurements were taken on both sides of 90 (51 male, 39 female) Kenyan human skulls. The distances from the center of pterion to the frontozygomatic suture were $38.88+3.49 \mathrm{~mm}$ on the right side and $38.24+3.47$ $\mathrm{mm}$ on the left side. The pterion was $30.35+3.40 \mathrm{~mm}$ and $30.34+4.34 \mathrm{~mm}$ above the mid point of the zygomatic arch on the right and left sides, respectively. Males had statistically significant higher pteria compared to females being $39.31+3.28 \mathrm{~mm}$ and $37.35+2.97 \mathrm{~mm}$ above the midpoint of the zygoma, respectively. Frontozygomatic suture and mid point of the zygoma can reliably be used in locating the pterion. This information may be useful in planning prior to surgery especially where neuronavigation devices equipments are scarce.

KEY WORDS: Pterion; Frontozygomatic suture; Zygoma; Kenyans.

\section{INTRODUCTION}

The pterion is an irregular $\mathrm{H}$ shaped sutural confluence in the temporal fossa of the skull formed by the frontal, parietal, sphenoid and temporal squama (Williams et al., 1998). This craniometric point is related to structures in the cranial cavity. The pterion marks the anterior middle meningeal arterial ramus (Williams et al.). Pterional fractures may therefore tear the frontal branch of middle meningial artery leading to extra dural haematoma (Lama \& Mottolese, 2000). Other structures related to the pterion include: middle cerebral artery, anterior pole of the insula and the Broca's area (Lindsay et al., 1991). Further, inferior border of the frontal lobe is represented by an oblique line drawn from the frontozygomatic suture to the pterion (Williams et al.).

The anatomic location of the pterion therefore is important in surgical interventions following extradural haemorrhage as well as tumors involving inferior aspects of the frontal lobe, such as olfactory meningiomas (Spektor $e t$ al., 2005). The 'pterional approach' may also be used in operations on the Broca's motor speech area (Lindsay et al.) and in repairing aneurysms of the middle cerebral artery as well as those of the upper basilar complex (Bage et al., 2002).
In neurosurgery, it is important to have the most suitable bony aperture in order to be minimally invasive (Ersoy et al., 2003). To achieve optimum craniotomy where neuronavigation devices are not available, the surgeon then relies on external landmarks, such as the pterion (Oguz et al., 2004). The position of the pterion however can not be discerned easily because it is usually covered by scalp (Williams et al.). This study therefore aimed at determining the position of the pterion using the mid point of the zygoma and the frontozygomatic suture as palpable points.

\section{MATERIAL AND METHOD}

Fifty adult dry skulls (31 male and 19 female) and forty formalin fixed cadaveric heads ( 20 male and 20 female) were used for this study. The dry skulls were obtained from the National Museums of Kenya. Those that had the $3^{\text {rd }}$ molar erupted were considered adults and were hence studied. The formalin fixed cadaveric heads were analyzed at the Department of Human Anatomy, University of Nairobi

\footnotetext{
* BSc Anatomy, MBChB. Department of Human Anatomy, University of Nairobi, Kenya.

** BDS, PhD. Department of Human Anatomy, University of Nairobi, Kenya.

${ }^{* * *}$ BSc Anatomy, MBChB, Mmed (Surg). Department of Human Anatomy, University of Nairobi, Kenya.
} 
Table I. Position of the pterion from the MPZ and FZS.

\begin{tabular}{lcccccc}
\hline & \multicolumn{3}{c}{ Gender } & \multicolumn{3}{c}{ Side } \\
\cline { 2 - 7 } & Male & Female & p-value & Left & Right & p-value \\
\hline MPZ $(\mathbf{m m})$ & $39.31+3.28$ & $37.35+2.97$ & 0.040 & $38.24+3.47$ & $38.88+3.49$ & 0.071 \\
FZS $(\mathbf{m m})$ & $30.73+3.74$ & $29.74+3.41$ & 0.069 & $30.34+4.30$ & $30.35+3.40$ & 0.062 \\
\hline
\end{tabular}

during routine dissection by level one students of medicine. Soft tissues were removed to expose the pterion.

Measurements were taken on both sides of the skull from the pterion to the midpoint of zygoma (MPZ) and to the frontozygomatic suture (FZS) using a Manutan $®$ digital vernier calipers with an accuracy of $0.001 \mathrm{~mm}$ (Fig. 1). Each of the measurements were taken twice then averaged so as to minimize bias errors. Data obtained were analysed using SPSS 11.5 (Chicago, Illinois) software. The Student's t-test was employed in the assessment of side and gender differences. $p$-value $\leq 0.05$ was considered significant.

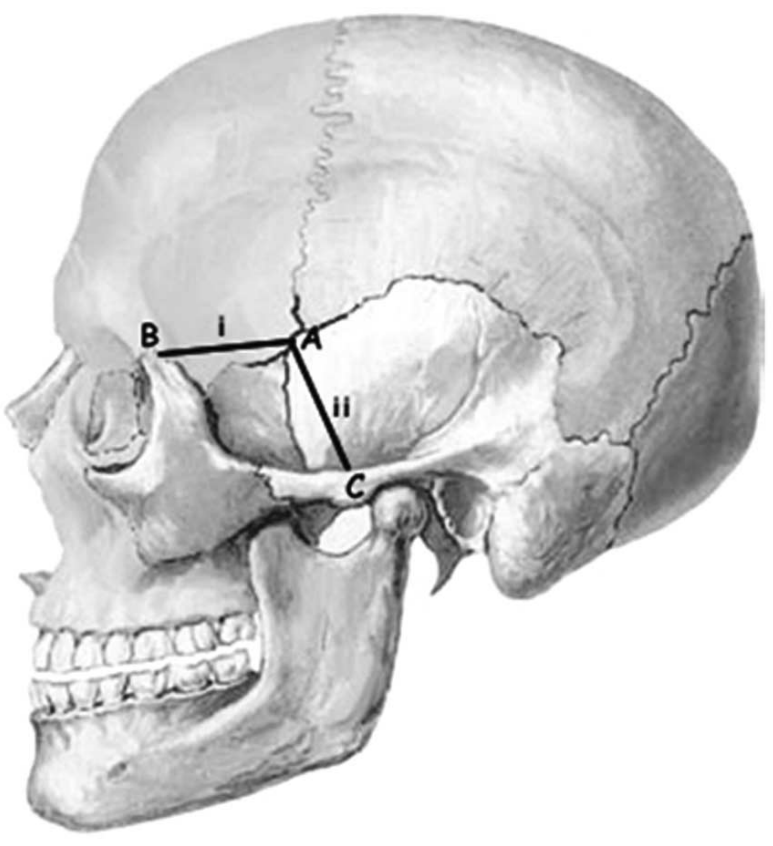

Fig. 1. Measurements taken on each skull. I, distance from the pterion (A) to the FZS (B); II, distance from the pterion to the MPZ (C).

\section{RESULTS}

The means and associated standard deviations of the various measurements taken from the pterion are presented in Table I below. No statistically significant side differences were found in the location of the pterion from the midpoint of the zygoma as well as from the frontozygomatic suture. As regards gender differences, the male pterion was significantly higher than the female one $(\mathrm{p}=0.040)$.

\section{DISCUSSION}

In the present study, the pterion was located $38.56+3.28 \mathrm{~mm}$ above the mid point of the zygoma. The pterion in Koreans was reported to be positioned 36.9+3.8 $\mathrm{mm}$ from the MPZ (Lee et al., 2001). Saxena et al. (1988) compared Nigerian skulls with those of Indians. They found the pteria in Nigerians were higher than those in Indian skulls. Further, the zygomatic process has been shown to be more prominent in Orientals than in Caucasians (Saxena et al.). The basis for these differences could be genetic or environmental (Ikedo et al., 1999).

The distance between pterion and mid point of the zygoma in the present study varied significantly among males and females. Males had higher pteria than females. This observation can be explained by morphometric studies on the skulls which have shown that female skulls are shorter and broader in proportion than the male ones (Williams et al.). According to Ikedo et al., the arch of the zygoma is more robust in males because of they have stronger muscles of mastication than females.

The present study has shown that the pterion is $30.35+3.61 \mathrm{~mm}$ posterior to the frontozygomatic suture. This is in tandem with descriptions that the pterion lies 30 to 35 $\mathrm{mm}$ away from the FZS (Williams et al.). The pterion in Koreans lied $26.8+4.5 \mathrm{~mm}$ away from the frontozygomatic suture (Lee et al.).

The pterion in the current study was located $30.35+3.40 \mathrm{~mm}$ posterior to the FZS on the right while the left pterion was $30.34+4.30 \mathrm{~mm}$ behind. Conversely, the pterion among male Turks lie $33.0+4.0 \mathrm{~mm}$ and $34.4+3.9$ $\mathrm{mm}$ behind the FZS on the right and left, respectively. The basis for the difference among the two populations could be genetic or evolutionary (Ikedo et al.). Gender differences in 
the location of this craniometric point were not significant though the male pterion was more posterior. This could be because of the larger size of skull in males (Williams et al.).

Since there was minimal side differences in all measurements used to locate the pterion, this landmark can reliably be located using the frontozygomatic suture and midpoint of the zygoma. This information may be useful in planning prior to surgery especially where neuronavigation devices equipments are scarce.

ACKNOWLEDGEMENTS. We are especially thankful to Dr. Julius Ogeng'o, Dr. Hassan Saidi and other teaching staff at the Department of Human Anatomy, University of Nairobi, for extending their valuable support in completing this study.

MWACHAKA, P.; HASSANALI, J. \& ODULA, P. Posición anatómica del pterion entre Kenianos para abordajes laterales de cráneo. Int. J. Morphol., 26(4):931-933, 2008.

RESUMEN: La pterion es un punto de confluencia sutural visto en la norma lateral del cráneo, donde se unen los huesos frontal, parietal, temporal y esfenoides. La posición del pterion exhibe variaciones en la población. La ubicación de este punto es importante en abordajes quirúrgicos a las fosas craneales anterior y la media. Mediciones específicas se han realizado en ambos lados de 90 cráneos humanos Kenyanos (51 varones, 39 mujeres). Las distancias desde el centro de pterion a la sutura frontocigomática fue de 38,88+3,49 $\mathrm{mm}$ en el lado derecho y $38,24+3,47 \mathrm{~mm}$ en el lado izquierdo. El pterion fue ubicado $30,35+3,40 \mathrm{~mm}$ y $30,34+4,34 \mathrm{~mm}$ por encima del punto medio del arco cigomático en los lados derecho e izquierdo, respectivamente. Los hombres presentaron un pterion estadísticamente significativo superior en comparación con las mujeres, siendo de 39,31+3,28 mm y 37,35+2,97 mm por encima del punto medio del cigoma, respectivamente. La sutura frontocigomática y el punto medio del cigoma pueden ser utilizados como referencia fiables para localizar a el pterion. Esta información puede ser útil en la planificación previa a la cirugía, sobre todo cuando los equipos dispositivos de neuronavegación son escasos.

PALABRAS CLAVE: Pterion; Sutura frontocigomática; Cigoma; Kenianos.

\section{REFERENCES}

Bage, E.; de Sola, G.; González, R.; Caniego, L. \& Cazon, C. Fusiform aneurysm of the middle cerebral artery. Rev. Neurol., 34:655-8, 2002.

Ersoy, M.; Evliyaoglu, C.; Bozkurt, M.; Konuskan, B. \& Tekdemir, I. Epipteric bone in the pterion may be a surgical pitfall. Minim. Invas. Neurosurg., 46:363-5, 2003.

Ikedo, T.; Nakamura, M. \& Itoh, M. Sex differences in the zygomatic angle in Japanese patients analyzed MRI with reference to Moire Fringe Patterns. Aesth. Plast. Surg., 23:349-53, 1999.

Lama, M. \& Mottolese, C. Middle meningeal artery aneurysm associated with meningioma. J. Neurosurg. Sci., 44:39-41, 2000.

Lee, U. Y.; Park, D. K.; Kwon, S. O.; Paik, D. J. \& Han, S. H. Morphological analysis of pterion in Korean. Korean J. Phys. Anthropol., 14(4):281-9, 2001.

Lindsay, K.; Bone, I. \& Callander, R. Neurology and neurosurgery illustrated. $2^{\text {nd }}$ Edn. Churchill Livingstone, Hong Kong, 1991. pp. 312-4.
Oguz, O.; Sanli, S.; Bozkir, M. \& Soames, W. The pterion in Turkish male skulls. Surg. Radiol. Anat., 26:220-4, 2004.

Saxena, S. K.; Jain, S. P. \& Chowdhary, D. S. A comparative study of pterion formation and its variations in the skulls of Nigerians and Indians. Anthropol. Anz., 46:75-83, 1988.

Spektor, S.; Valarezo, J.; Fliss, D.; Cohen, J. \& Goldman, J. Olfactory Groove Meningiomas from Neurosurgical and Ear, Nose, and Throat Perspectives: Approaches, Techniques, and Outcomes. Neurosurgery, 57(4):268-80, 2005.

Williams, L.; Bannister, L.; Berry, M.; Collins, P.; Dyson, M. \& Dussek, E. Gray's Anatomy. 38 ${ }^{\text {th }}$ Edn. Churchill Livingstone, London, 1998.

Correspondence to:

Philip Maseghe Mwachaka

Department of Human Anatomy

University of Nairobi

P. O. Box $30197-00100$ GPO

Nairobi

KENYA

Email : pmaseghe@yahoo.com

Received: 28-09-2008 Accepted: $25-10-2008$ 
